\title{
Magnesium Therapy Prevents Senescence with the Reversal of Diabetes and Alzheimer's Disease
}

\author{
Ian James Martins ${ }^{1,2,3}$ \\ ${ }^{1}$ Centre of Excellence in Alzheimer's Disease Research and Care, School of Medical Sciences, Edith Cowan \\ University, Joondalup, Australia \\ ${ }^{2}$ School of Psychiatry and Clinical Neurosciences, The University of Western Australia, Nedlands, Australia \\ ${ }^{3}$ McCusker Alzheimer's Research Foundation, Holywood Medical Centre, Nedlands, Australia \\ Email: i.martins@ecu.edu.au
}

Received 20 April 2016; accepted 24 May 2016; published 27 May 2016

Copyright (C) 2016 by authors and Scientific Research Publishing Inc.

This work is licensed under the Creative Commons Attribution International License (CC BY).

http://creativecommons.org/licenses/by/4.0/

(c) (i) Open Access

\section{Abstract}

In the current global epidemic for Non Alcoholic Fatty Liver Disease (NAFLD), diabetes and neurodegenerative diseases such as Alzheimer's disease there has been a major interest in magnesium therapy to delay the severity of NAFLD, Type 3 diabetes and neurodegeneration in the developing and developed world. The objective of magnesium therapy is to activate the anti-aging gene Sirtuin 1 (Sirt1) to prevent cardiovascular disease, NAFLD and diabetes. Reduced consumption of nutrients such as fatty acids, glucose, cholesterol and increased magnesium consumption is closely linked to reduced bacterial lipopolysaccharides (LPS) and activation of Sirt1 relevant to active nuclear and mitochondria interactions with the prevention of myocardial infarction and Type 3 diabetes. Magnesium deficiency and its effects on Sirt1 regulation have become important with magnesium deficiency associated with appetite dysregulation, senescence, glucose/nitric oxide dyshomeostasis, increased ceramide and toxic amyloid beta formation. Magnesium therapy activates the peripheral sink amyloid beta clearance pathway with the reversal of cell senescence associated with various chronic diseases such as cardiovascular disease, Type 3 diabetes and Alzheimer's disease.

\section{Keywords}

Magnesium, Cholesterol, Amyloid Beta, Infarct, Lipopolysaccharides

\section{Introduction}

Interests in chronic diseases have increased globally with the release of the World Health Organization (WHO, 
2013) which reported that the global death related to chronic disease was $63 \%$ with $48 \%$ attributed to cardiovascular disease, $21 \%$ to cancer and $12 \%$ to chronic respiratory disease. The global epidemic in obesity and diabetes has affected both the developing and developed world with neuroendocrine disease that involves insulin and leptin resistance linked to kidney disease, thyroid dysfunction, Non Alcoholic Fatty Liver Disease (NAFLD) and rheumatoid arthritis [1] [2]. The early senescence of cells in global populations has recently been associated with the anti-aging gene Sirtuin 1 (Sirt1) and its down regulation has been associated with mitochondrial apoptosis with relevance to diabetes and neurodegeneration [3] [4].

Sirt1 is a Nicotinamide Adenine Dinucleotide (NAD) + dependent class III histone deacetylase protein that targets nuclear receptors to regulate several cell functions by deacetylating both histone and non-histone targets [5]. Sirt1 regulation of transcription factors adapts gene expression to metabolic activity, insulin resistance and inflammation in chronic diseases [6]-[10]. Nutritional regulation (calorie restriction and high fat feeding) of Sirt1 that is involved in the hypothalamic and suprachiasmatic nucleus control of food intake with regulation of the central melanocortin system via the fork head transcription factor has been reported [11]-[14]. Sirt1 dysregulation has been closely linked with alterations in appetite regulation and low adiponectin levels with circadian clock disorders that are now important to Type 3 diabetes [3] [15] [16]. In support of Sirt1's role in circadian rhythms subjects carrying minor alleles at Sirt1 and clock loci, displayed a higher resistance to weight loss as compared with homozygotes for both major alleles, suggesting links between the circadian clock and Sirt1 function [17]-[19]. Sirt1 is involved in neuron proliferation and glucose homeostasis with effects on cellular cholesterol and lipid homeostasis by the regulation of Liver X Receptor (LXR) proteins [3] [4].

The rate of the most prevalent chronic disease such as cardiovascular disease and acute myocardial infarction is linked to the metabolic syndrome and interest in magnesium/Sirt1 interactions associated with the development of coronary artery atherosclerosis has become important [20]-[23] (Figure 1). Reversal of cell senescence involves magnesium and Sirt1 interactions that improve appetite dysregulation connected to autonomous disease and Type 3 diabetes in a population by activation of other anti-aging genes that may delay the rate of chronic diseases [24] [25] (Figure 1). Autonomous disease that involves magnesium and Sirt1 dysregulation may be relevant to defective calcium ion channel activity and linked to emergency acute myocardial infarction and ischemic heart disease [26]-[28] and may not be relevant to levels of CK-MB and statin use [29]-[32]. Other

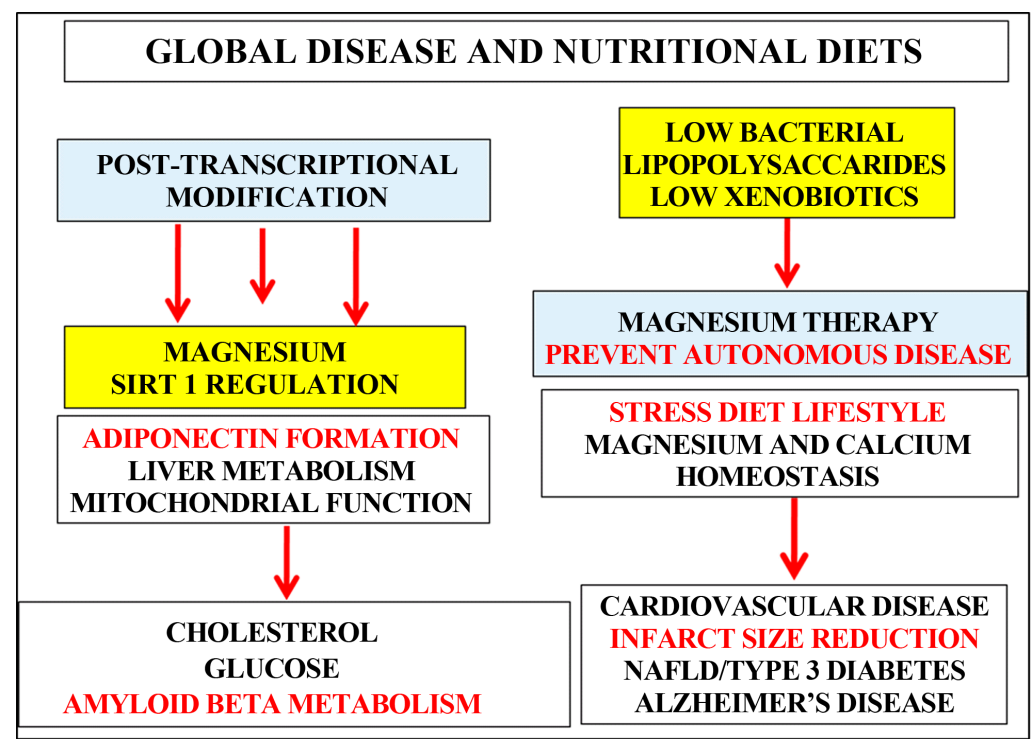

Figure 1. Anti-aging therapy that involves magnesium and Sirt1 interactions are required to improve appetite dysregulation and brain-liver connections with relevance to chronic diseases and Type 3 diabetes in global populations. Nutritional diets are required to prevent Sirt1 dysregulation that occurs with aging and associated with emergency acute myocardial infarction. Nutrition and magnesium therapy prevent bacterial lipopolysaccharides and xenobiotics to induce post-transcriptional modifications with the prevention of magnesium/Sirt1 dysregulation in diabetes and Alzheimer's disease that involve glucose dyshomeostasis, hypercholesterolemia and calcium associated toxic amyloid beta formation with relevance to myocardial infarction in global populations. 
anti-aging genes [24] [25] may be involved with magnesium therapy and the regulation of mitochondrial apoptosis in various cells and tissues [25]. Appetite dysregulation and Type 3 diabetes have been linked to higher brain dysregulations (higher cerebral cortex areas) that corrupt the hypothalamus, sympathetic and non-sympathetic nervous system with close connections between magnesium and Sirt1 in the regulation of the circadian rhythm [4] [33], stroke [34]-[37], NAFLD [38]-[40] diabetes [41]-[47] and neurodegenerative diseases [48][52].

Detailed studies have previously shown the involvement of magnesium therapy in cholesterol metabolism with relevance to cardiovascular disease that is associated with low plasma High Density Lipoprotein (HDL), and high Low Density Lipoprotein (LDL) cholesterol levels [26] [27]. Stress, diet and lifestyles are closely linked to imbalances [53] in magnesium therapy that may accelerate aging with disturbances in eating [54], growth and nutrient metabolism that may involve dietary fat/carbohydrate [55]-[58] (Figure 1). Diets that contain xenobiotics [39]/bacterial lipopolysaccharides (LPS) are involved in post-transcriptional modifications with magnesium/Sirt1 dysregulation in diabetes and Alzheimer's disease that may involve toxic amyloidogenic pathways and myocardial infarction in global populations [59]-[63].

\section{Magnesium Therapy Regulates Amyloid Beta Metabolism with Implications for NAFLD and Cardiovascular Disease}

In the developing and developed world NAFLD now afflicts $60 \%$ of the global population with the metabolic syndrome as the major disorder in these obese/diabetic individuals [3] [39] [40]. The increased risk for acute myocardial infarction has become of concern with NAFLD associated with poor hepatic xenobiotic and LPS [63]-[66] that may now be the factors involved in the induction of toxic amyloid beta (A $\beta$ ) associated with NAFLD and cardiovascular disease in global populations. Sirt1 down regulation promotes abnormal hepatic cholesterol homeostasis that exist as the primary cellular mechanism involved in the inactivation of the peripheral sink $(\mathrm{A} \beta)$ clearance pathway with generation of toxic $\mathrm{A} \beta$ involved in cardiovascular disease and the risk for death [59]-[62].

$\mathrm{A} \beta$ [67] is a proteolytic product of a larger protein, the amyloid precursor protein (APP). The A $\beta$ (1-40) is synthesized in the early secretory and endocytic cellular pathways and the $A \beta$ (1-42) is generated mainly in the secretory pathway [68]. APP is cleaved by three proteases, classified as $\alpha, \beta$ and $\gamma$ secretases and formation of $\mathrm{A} \beta$ from APP is thought to occur via a two step process involving the $\beta$-site cleaving enzyme (BACE) and the putative $\gamma$-secretases [69]-[71]. The APP protein is cleaved into $\beta$ APPs (amino acids 18-671 of APP) and A $\beta$ (amino acids 672-711/713 of APP). Apolipoprotein E (apo E) is important in lipid metabolism with multiple roles in cell biology and is involved in the understanding of how apo E4 promotes risk of neurodegeneration [72]. The understanding of apo E mediated hepatic $\mathrm{A} \beta$ [72] clearance has become important with the alterations in apo $\mathrm{E} / \mathrm{A} \beta$ interactions responsible for defective peripheral clearance of $\mathrm{A} \beta$ associated with various chronic diseases [4].

Magnesium and its involvement in apo E/A $\beta$ interactions determine cellular apo E expression [73] [74] and cholesterol metabolism [75]-[77] with relevance to $\mathrm{A} \beta$ oligomer formation and magnesium alterations determine $\mathrm{A} \beta$ flux from the brain to the liver [4]. Cholesterol has been shown to be directly involved in membrane APP/A $\beta$ interactions and magnesium levels have been shown to determine cholesterol metabolism involved in the early stages of organ disease and amyloidosis [78]-[80]. Magnesium has been shown to regulate APP and A $\beta$ processing with dietary levels of magnesium important to maintain synaptic plasticity, cognitive decline with the prevention of Alzheimer's disease (AD) [81]-[85]. Magnesium and its involvement in hypercholesterolemia, toxic amyloid beta formation also include ceramide formation with relevance to cardiovascular disease [86] [87].

Interests in magnesium homeostasis with relevance to intestinal magnesium absorption and kidney excretion provide important evidence of the relevance of the global kidney epidemic to magnesium deficiency in cells [88]. Obese and diabetic individuals are at increased risk for kidney disease with obvious implications of magnesium disturbances in various cells and tissues. The absent peripheral sink amyloid beta pathway in insulin resistant individuals may be relevant to kidney disease and magnesium imbalance. Magnesium play an important role in ATP formation in the mitochondria with ATP critical to A $\beta$ misofolding and APP and A $\beta$ involved in ATP generation in the mitochondria [89]-[92]. Magnesium imbalance in cells are associated with mitochondrial apoptosis [93] and $\mathrm{A} \beta$ oligomer formation with defective energy metabolism that indicate induction of NAFLD and 
obesity in global populations [3] [39] [40].

The anti-aging gene Sirt1 is involved in $\mathrm{A} \beta$ metabolism [3] and the biogenesis of the mitochondria and magnesium/Sirt1 interactions are possibly essential for maintenance of energy metabolism in various cells and tissues [3]. Magnesium/Sirt1 interactions involve anti-aging effects by telomere length regulation in the nucleus with both magnesium and Sirt1 involved in telomerase activity [94]-[96]. The role of magnesium in RNA interactions and stability are critical to Sirt1 regulation of cellular lipid metabolism and energy expenditure [97][101]. Sirt1 is involved with the transcription factor p53 deacetylation with post-transcriptional regulation of cells (Figure 2) in the liver (NAFLD), adipose tissue (obesity) and brain (neurodegeneration) that involve both lipid and glucose metabolism [3] [4]. The relevance of p53/Sirt1 interactions and magnesium/p53 interaction [102] have become critical with relevance to Sirt1 down regulation by inhibitors [25] that override magnesium transactivation of Sirt1 (Figure 2) with acceleration of myocardial infarction in global populations [103]-[108]. Furthermore magnesium regulation of neuron and mitochondria apoptosis via N-methyl-d-aspartate (NMDA) receptor calcium loading involves p53/Sirt1 interactions with relevance to transcriptional regulation by magnesium of neuron and mitochondria apoptosis in Type 3 diabetes and AD [109]-[113].

Sirt1's role in vasodilation of the coronary arteries has become important with the discovery of apelin that with Sirt1 are involved with nitric oxide (NO) regulation (Figure 2) in endothelial cells [114]. Sirt1 inhibitors prevent magnesium independent regulation of NO in endothelium with the development of coronary artery vasoconstriction [115]-[117]. Apelin and release from adipose tissue [114] involves conversion to angiotensin II (Ang II) and magnesium supplementation is essential to prevent Ang II induced myocardial damage [118]-[122]. Interests in Ang II and magnesium regulation of cell calcium homeostasis [123] [124] has accelerated with the role magnesium in the regulation of myocardium calcium channel function and now is associated with apelin's regulation of sarco endoplasmic calcium [125]-[129].

Magnesium and its regulation of adiponectin levels [130] [131] and adiponectin connections to myocardial infarction in man [132]-[134] has become of importance with the role of magnesium involved in cell calcium homeostasis (mitochondrial function) and formation of high molecular weight adiponectin [135] [136]. Adiponectin is mainly secreted from the adipose tissue into the bloodstream and inversely correlated with body fat in adults. Adiponectin self-associates into larger structures from trimers to form hexamers or dodecamers with the high-molecular weight form biologically more active with regard to regulation of glucose homeostasis, NMDA glutamate receptor [137] and appetite regulation (Figure 2). Dysregulated Sirt1 in adipocyte differentiation and senescence [138]-[142] involve the down regulation of adiponection gene expression and secretion

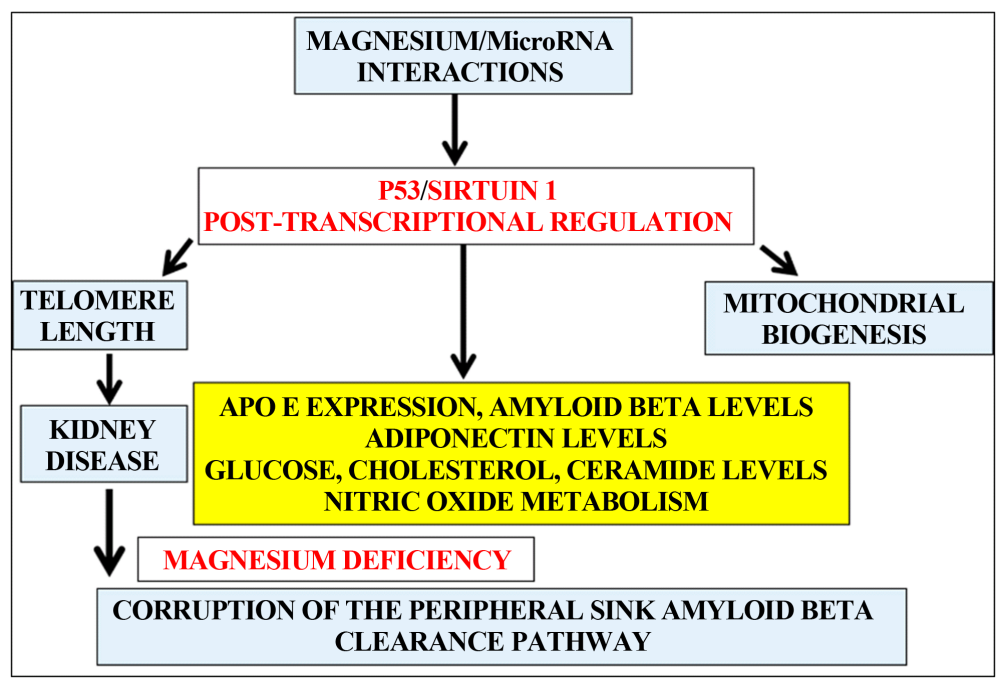

Figure 2. The importance of magnesium and RNA interactions in the post-transcriptional regulation of Sirt1 has become important to the maintenance of the peripheral sink amyloid beta clearance pathway. Magnesium and Sirt1 are involved in telomere length and mitochondrial biogenesis and regulate cholesterol and ceramide contents of cells. p53/Sirt1 downregulation and kidney disease (low magnesium) are associated with low adiponectin levels with relevance to hyperglycemia, toxic amyloid beta formation and abnormal nitric oxidemetabolism. 
[143]-[145]. Sirt1 is clearly involved in adiposity with adipocyte size negatively correlated with adiponectin levels, adipose tissue ceramide metabolism and HDL levels [146]-[149]. The connections between magnesium/ Sirt1 interactions involve adiponectin levels with relevance to calcium and toxic amyloid beta metabolism [41], NAFLD and myocardial infarction in man.

Magnesium therapy in age related diseases has become essential with magnesium deficiency involved in mitochondrial apoptosis with relevance to diseases of the heart, liver, brain, immune system and reproductive system [27] [150]-[155]. In the current global kidney epidemic the loss of magnesium in the urine is the inducing factor in magnesium deficiency involved in Sirt1 dysregulation and induction of apoptosis of various cells. The interactions of magnesium with Sirt1 (Figure 2) has become important with magnesium therapy involved with Sirt1 regulation of mitochondrial biogenesis and prevention of toxic amyloid beta formation relevant to the reduced susceptibility to senescence in various cells and tissues. The connections between magnesium and cancer has become important with magnesium therapy essential to maintain magnesium/Sirt1 interactions with the prevention of insulin resistance and cancer [156]. Dysregulation of miRNA/Sirt1 interactions by magnesium deficiency induces cancer [157] by downregulation of p53 induced by decreased intracellular magnesium levels with the corruption of nuclear and mitochondria connections.

\section{LPS Disrupts Magnesium Therapy with Relevance to Albumin and Amyloid Beta Oligomer Metabolism}

Atherogenic diets that contain high fat contents have been discouraged in various communities with the role of these fat diets in the transport of gut microbiotica [15] that increase plasma endotoxins such as lipopolysaccarides (LPS) (Figure 3) in the blood plasma [15]. LPS has been associated with metabolic diseases and diabetes [63]-[66]. Lipoproteins such as chylomicrons that are produced after a high fat diet contain the LPS binding protein (LBP) that bind LPS and essential interactions of LPS to apo B containing cholesterol-rich lipoproteins clearly implicate dietary fat and LPS [63]-[66] in peripheral A $\beta$ metabolism in diabetes with relevance to neurodegenerative diseases. LPS are endotoxins and essential components of the outer membrane of gram negative bacteria and consist of covalently linked segments, surface carbohydrate polymer, core oligosaccharide and acylated glycolipid that can bind to cell membranes to alter membrane interactions [158].

Cholesterol is an essential membrane component and in association with phospholipids, glycosphingolipids such as ceramide or gangliosides, glycerophospholipids (plasmalogen) and sterols make up the membrane bilayers in cells. LPS may influence membrane cholesterol by binding to cell membranes and lipoproteins and its packing in the membrane allows the increased interaction or displacement of the $\mathrm{A} \beta$ peptide. LPS can rapidly insert into cell membranes with a preference for insertion and partition into cholesterol/sphingomyelin domains in cell membranes [159]-[161]. Lipid rafts containing sphingomyelin and cholesterol form microdomains in cell membranes for the recruitment of lipid modified proteins such as $\mathrm{A} \beta$ oligomers with the binding of these hydrophobic proteins to membranes. The essentiality of cholesterol determines $\mathrm{A} \beta$ binding to membranes [72] with cholesterol and magnesium now important to effects of LPS on the metabolism of toxic A $\beta$ oligomers in cells (Figure 3).

LPS alter magnesium regulation of hepatic cholesterol metabolism and the immune response [162]-[164] with an increase hepatic cytokines and APPs [66] with effects on cholesterol mediated amyloidosis. Magnesium and its relevance to hepatic cholesterol metabolism is associated with the structure and stability of cholesterol/ sphingomyelin domains with magnesium deficiency associated with increased ceramide [86] [87] that interferes with membrane cholesterol (alkyl chain/C17 position) metabolism with decreased clearance of cholesterol-rich lipoproteins [165]. In LPS induced membrane alterations the magnesium regulation of membrane fluidity is altered [166]-[168] with increased cholesterol and ceramide contents that promote $\mathrm{A} \beta$ aggregation and fibril formation with increased risk for myocardial infarction (Figure 3). LPS and its regulation of hepatic membrane cholesterol metabolism involves phospholipid transfer protein (PLTP) involved in vitamin E, phospholipid and $\mathrm{A} \beta$ transport in cell membranes [169]-[174] with LPS involved in PLTP transport that supersedes membrane vitamin E transport [64] with relevance to magnesium therapy and hepatic lipid metabolism. Increased levels of vitamin E administration in rats prevent LPS mediated hepatic damage [175] with facilitation of peripheral amyloid beta clearance.

The understanding of the role of the peripheral sink A $\beta$ hypothesis in AD implicates LPS of central importance in the corruption of magnesium therapy that involves peripheral cholesterol metabolism, PLTP activity 


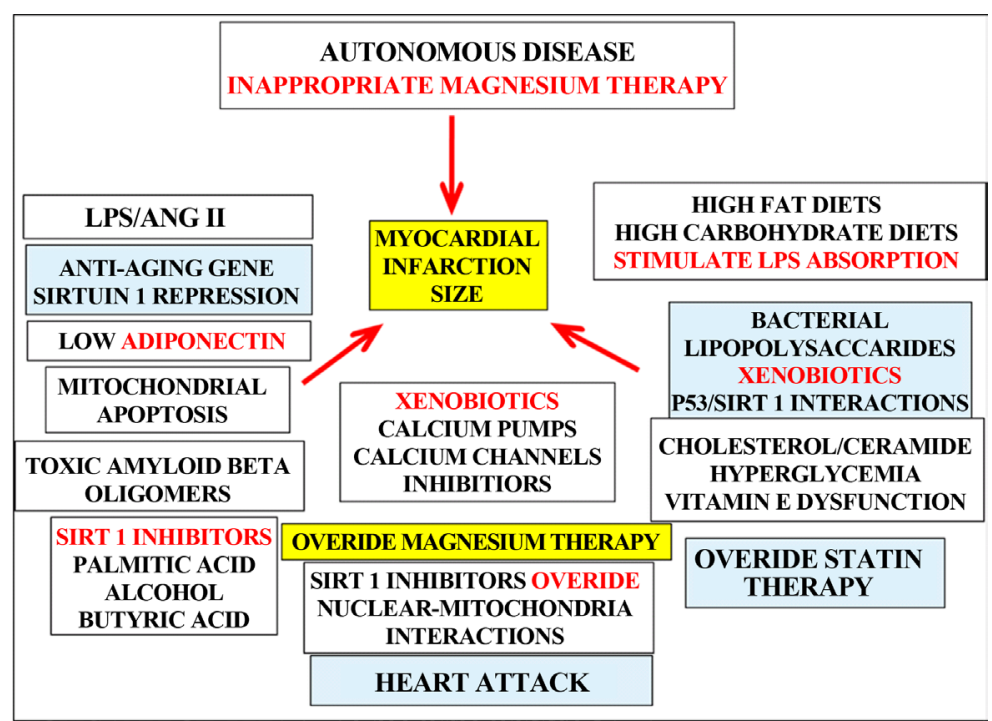

Figure 3. Atherogenic diets that are high in fat transport LPS into the blood plasma associated with metabolic diseases and diabetes. LPS interfere with magnesium therapy and regulation of hepatic cholesterol and peripheral amyloid beta metabolism with relevance to diabetes and neurodegenerative diseases. LPS, xenobiotics, Sirt1 inhibitors (alcohol, palmitic acid, butyric acid) interferes with magnesium therapy via p53/Sirt1 regulation of cells with increased inflammation and with relevance to cardiovascular disease. Ang II interfere with magnesium homeostasis with effects on Sirt1 actions that involve adiponectin, toxic amyloid beta formation, mitochondrial apoptosis and myocardial infarct size.

and the role of various acute phase proteins involved in $\mathrm{A} \beta$ aggregation [72]. LPS corruption of magnesium therapy involve the reduced release of albumin [176]-[181] from the liver with effects on albumin mediated fatty acid transport with plasma albumin important to maintain therapeutic free magnesium levels in cells such as the liver and brain and therapeutic levels of albumin important to prevent peripheral and brain $\mathrm{A} \beta$ aggregation [64]. The plasma magnesium levels need to be corrected with relevance to albumin (Albumin-corrected magnesium = magnesium +0.005 (40-albumin) and values expressed as mg/albumin contents [176] [177] with relevance to LPS induced $\mathrm{A} \beta$ oligomer formation and size of the myocardial infarct [182]-[184]. LPS interferes with p53/ Sirt1 regulation of cells with increased inflammation and hepatocyte apoptosis [185] with importance to the p53 regulation of cardiac rupture [103] [104] (Figure 3).

\section{Unhealthy Diets, Exercise and Stress Prevent Magnesium Therapy and Accelerate Chronic Diseases}

Stressors that disturb adaptive functions early in life may not protect the organism from the environment and magnesium imbalance linked to stress, exercise [186]-[188], diet (high carbohydrate) and lifestyle have become important to prevent NAFLD and Type 3 diabetes with elevated risk of early myocardial infarction [182]-[184]. A low calorie diet is essential and recommended for the treatment of NAFLD and obesity and the benefit of this dietary regime is quite likely to lead to Sirt1 activation with improved peripheral cholesterol metabolism and reduced effects of LPS. Diet that are high in fat promote LPS absorption [4] and high fat diet have been also associated with magnesium deficiency. Sirt1 inhibitors such as alcohol, palmitic acid and butyric acid [24] (Figure 3) should be avoided with low palmitic acid diets essential for prevention of NAFLD and for rapid liver metabolism of glucose, cholesterol and amyloid beta. Stress and the neuroendocrine system are closely involved in appetite regulation with the corruption of the apelinergic pathway [114] associated with kidney disease (magnesium deficiency), NAFLD and reduced $\mathrm{A} \beta$ oligomer metabolism [114].

Healthy food consumption an exercise may not eradicate the obesity epidemic or chronic diseases in the Western world since various xenobiotics (Figure 3) present in the food [39] such as the phthalates which affect the nuclear receptors (PPAR-Sirt1) are possibly involved in the induction of NAFLD, insulin resistance and chronic diseases associated with obesity. Antioxidants and minerals (magnesium, zinc) that improve genomic stability and reduce free radical damage of cells include vitamins such as C, D and E essential for cell function. 
Xenobiotics interfere with magnesium binding to DNA with effects on zinc/Sirt1 protection and risk for damage to various cells with chronic disease [189]-[192]. Addition of resveratrol to the diet has been shown to activate Sirt1 with the prevention of NAFLD in animal models [4]. Magnesium needs to be consumed at a dose of 260 mg/day (males) and $220 \mathrm{mg} /$ day (females) in global communities that involve exercise as a daily basis and essential for individuals from developed countries/developing countries to avoid xenobiotic toxicity from elevated xenobiotic exposure present in food, water and air [39]. Xenobiotics have been shown to override magnesium related regulation of calcium homeostasis by interference of calcium channels and pumps with relevance to cardiac contraction [189]-[191].

High fibre diets [78] that contain fruit and vegetables and have become important for the treatment of NAFLD with therapeutic potential to the heart and brain and these diets prevent adverse affects on magnesium dysfunction and calcium-membrane lipid interactions [41] have become important to the prevention of accelerated aging associated with NAFLD, toxic A $\beta$ formation and myocardial infarction. Specific polyphenols found in vegetables and fruits need careful evaluation since high doses [40] may cause increased oxidative stress with toxicity to the liver and induction of NAFLD and chronic disease. Nutritional interests in pyruvic acid consumption (6 44 g/day) [40] have increased with pyruvic acid as a Sirt1 activator and leucine consumption associated with increased adiponectin levels and reduced cholesterol levels in rats and glucose levels in obese mice [40]. Interest in leucine administration in man has increased with the effects of leucine on appetite regulation and Sirt1 activation [40].

Magnesium dysfunction versus magnesium deficiency in cell and tissues has become important to the treatment of various diseases with Sirt1 inhibitors (Figure 3) that corrupt magnesium DNA effects in various cells. Otherwise in various cells and tissues chronic disease may be related to calcium dyshomeostasis that involve calcium ion channel dysfunction by xenobiotics and not related to magnesium imbalance within cells. In the aging process magnesium deficiency is the most common disorder associated with poor intestinal absorption magnesium and associated with various chronic diseases. Magnesium therapy now involves the use of various products that stimulate the absorption of magnesium into the blood and magnesium supplementation has been introduced to manage insulin resistance, NAFLD and cardiovascular disease [192] [193]. Magnesium dysfunction induces Type 3 diabetes [15] [16] with brain insulin resistance (Figure 3) closely connected to magnesium levels (Sirt1 regulation), glucose dyshomeostasis, LPS induced repression of Sirt1 [194] with relevance to A $\beta$ oligomer formation. High fibre diets that contain short chain fatty acids [195] [196] have been shown to stimulate magnesium absorption with relevance to management of insulin resistance and NAFLD. The anti-aging protein Sirt1 is involved with the intestinal absorption of nutrients [197] and with the aging process Sirt1 down regulation is now linked to cell senescence and apoptosis and possibly connected to malabsorption, intestinal disease and magnesium imbalances in man. Sirt1 has been closely linked to A $\beta$ metabolism in AD (Figure 1) and $\alpha$-synuclein metabolism in PD [65] with circadian dysregulation that is associated with protein aggregation and with implications to magnesium/Sirt1 research and therapeutics in the regulation of $\alpha$-synuclein/A $\beta$ aggregates in the prevention of early cell senescence in and cardiovascular disease [198] [199].

\section{Conclusion}

Early cell senescene with relevance to Sirt1 has become important to the prevention of various chronic diseases that include cardiovascular disease, NAFLD and Type 3 diabetes. Interest in magnesium therapy has accelerated to maintain Sirt1 activity that may prevent mitochondrial apoptosis that afflicts many of the global chronic diseases. Magnesium/Sirt1 interactions are critical to cellular cholesterol metabolism, glucose metabolism, energy expenditure and defective post-transcriptional regulation of cells via the p53/Sirt1 pathway corrupt magnesium therapy with relevance to toxic $\mathrm{A} \beta$ formation and myocardial infarction. Magnesium therapy and Sirt1 regulation of adiponectin and $\mathrm{A} \beta$ formation are closely linked maintenance of the adipose-liver interactions that maintain the peripheral $\mathrm{A} \beta$ clearance pathway with the prevention of NAFLD, Type 3 diabetes and AD. Ang II down regulation of magnesium/Sirt1 interactions connects calcium dyshomeostasis to toxic amyloid beta formation and to myocardial infarction. Diets high in fat/carbohydrate are connected to magnesium deficiency and these diets promote the absorption of bacterial lipopolysaccharides that interfere with magnesium/Sirt1 regulation of hepatic membrane cholesterol homeostasis with relevance to toxic $\mathrm{A} \beta$ formation. Lifestyles that involve stress, exercise and unhealthy diets lead to abnormal magnesium therapy with inactivation of Sirt1 with early cell senescence and induction of autonomous disease associated with cardiac rupture, NAFLD and Type 3 diabetes. 


\section{Acknowledgements}

This work was supported by grants from Edith Cowan University, the McCusker Alzheimer’s Research Foundation and the National Health and Medical Research Council.

\section{References}

[1] James, P.T., Rigby, N. and Leach, R. (2004) The Obesity Epidemic, Metabolic Syndrome and Future Prevention Strategies. European Journal of Preventive Cardiology, 11, 3-8. http://dx.doi.org/10.1097/01.hjr.0000114707.27531.48

[2] Flegal, K.M., Kit, B.K., Orpana, H. and Graubard, B.I. (2013) Association of All Cause Mortality with Overweight and Obesity Using Standard Body Mass Index Categories: A Systematic Review and Meta-Analysis. The Journal of the American Medical Association, 309, 71-82. http://dx.doi.org/10.1001/jama.2012.113905

[3] Martins, I.J. (2015) Unhealthy Nutrigenomic Diets Accelerate NAFLD and Adiposity in Global Communities. Journal of Molecular and Genetic Medicine, 9, 1-11.

[4] Martins, I.J. (2015) Nutritional and Genotoxic Stress Contributes to Diabetes and Neurodegenerative Diseases Such as Parkinson's and Alzheimer's Diseases. In: Atta-ur-Rahman, Ed., Frontiers in Clinical Drug Research, CNS and Neurological Disorders, Vol. 3, 158-192. http://dx.doi.org/10.2174/9781608059263114030008

[5] Guarente, L. (2007) Sirtuins in Aging and Disease. Cold Spring Harbour Symposium Quantitative Biology, 72, 483488. http://dx.doi.org/10.1101/sqb.2007.72.024

[6] Hansen, M.K. and Connolly, T.M. (2008) Nuclear Receptors as Drug Targets in Obesity, Dyslipidemia and Atherosclerosis. Current Opinion in Investigational Drugs, 9, 247-255.

[7] Harrison, C. (2012) Neurodegenerative Disorders: A Neuroprotective Role for Sirtuin 1. Nature Reviews Drug Discovery, 11, 108. http://dx.doi.org/10.1038/nrd3672

[8] Kawada, T., Goto, T., Hirai, S., Kang, M.S., Uemura, T. and Yu, R. (2008) Dietary Regulation of Nuclear Receptors in Obesity-Related Metabolic Syndrome. Asia Pacific Journal of Clinical Nutrition, 17, 126-130.

[9] Swanson, H.I., Wada, T., Xie, W., Renga, B., Zampella, A. and Distrutti, E. (2013) Role of Nuclear Receptors in Lipid Dysfunction and Obesity-Related Diseases. Drug Metabolism \& Disposition, 41, 1-11. http://dx.doi.org/10.1124/dmd.112.048694

[10] Cakir, I., Perello, M., Lansari, O., Messier, N.J., Vaslet, C.A. and Nillni, E.A. (2009) Hypothalamic Sirt1 Regulates Food Intake in a Rodent Model System. PLoS ONE, 4, e8322. http://dx.doi.org/10.1371/journal.pone.0008322

[11] Kitamura, T. and Sasaki, T. (2012) Hypothalamic Sirt1 and Regulation of Food Intake. Diabetology International, 3 , 109-112. http://dx.doi.org/10.1007/s13340-012-0088-5

[12] Dietrich, M.O., Antunes, C., Geliang, G., Liu, Z.W., Borok, E. and Nie, Y.Z. (2010) Agrp Neurons Mediate Sirt1’s Action on the Melanocortin System and Energy Balance: Roles for Sirt1 in Neuronal Firing and Synaptic Plasticity. Journal of Neuroscience, 30, 11815-11825. http://dx.doi.org/10.1523/JNEUROSCI.2234-10.2010

[13] Schaffhauser, A.O., Madiehe, A.M., Braymer, H.D., Bray, G.A. and York, D.A. (2002) Effects of a High-Fat Diet and Strain on Hypothalamic Gene Expression in Rats. Obesity Research, 10, 1188-1196. http://dx.doi.org/10.1038/oby.2002.161

[14] Lee, A.K., Mojtahed-Jaberi, M., Kyriakou, T., Astarloa, E.A.O., Arno, M. and Marshall, N.J. (2010) Effect of High-Fat Feeding on Expression of Genes Controlling Availability of Dopamine in Mouse Hypothalamus. Nutrition, 26, 411422. http://dx.doi.org/10.1016/j.nut.2009.05.007

[15] Martins, I.J. (2015) Diabetes and Organ Dysfunction in the Developing and Developed. World Global Journal of Medical Research: F Diseases, 15, 1-6.

[16] Martins, I.J. (2016) Diet and Nutrition Reverse Type 3 Diabetes and Accelerated Aging linked to Global Chronic Diseases. Journal of Diabetes Research Therapy, 2, 1-6.

[17] Garaulet, M., Esteban Tardido, A., Lee, Y.C., Smith, C.E., Parnell, L.D. and Ordovás, J.M. (2012) SIRT1 and CLOCK 3111T>C Combined Genotype Is Associated with Evening Preference and Weight Loss Resistance in a Behavioral Therapy Treatment for Obesity. International Journal of Obesity, 36, 1436-1441. http://dx.doi.org/10.1038/ijo.2011.270

[18] Shimoyama, Y., Suzuki, K., Hamajima, N. and Niwa, T. (2011) Sirtuin 1 Gene Polymorphisms Are Associated with Body Fat and Blood Pressure in Japanese. Translational Research, 157, 339-347. http://dx.doi.org/10.1016/j.trsl.2011.02.004

[19] Clark, S.J., Falchi, M., Olsson, B., Jacobson, P., Cauchi, S. and Balkau, B. (2012) Association of Sirtuin 1 (SIRT1) Gene SNPs and Transcript Expression Levels with Severe Obesity. Obesity (Silver Spring), 20, 178-185. http://dx.doi.org/10.1038/oby.2011.200 
[20] Swaminathan, R. (2003) Magnesium Metabolism and Its Disorders. Clinical Biochemistry Review, 24, 47-66.

[21] Barbagallo, M. and Dominguez, L.J. (2010) Magnesium and Aging. Current Pharmaceutical Design, 16, 832-839. http://dx.doi.org/10.2174/138161210790883679

[22] Killilea, D.W. and Maier, J.A.M. (2008) A Connection between Magnesium Deficiency and Aging: New Insights from Cellular Studies. Magnesium Research, 21, 77-82.

[23] Rowe, W.J. (2012) Correcting Magnesium Deficiencies May Prolong Life. Clinical Interventions in Aging, 7, 51-54. http://dx.doi.org/10.2147/CIA.S28768

[24] Martins, I.J. (2016) Anti-Aging Genes Improve Appetite Regulation and Reverse Cell Senescence and Apoptosis in Global Populations. Advances in Aging Research, 5, 9-26. http://dx.doi.org/10.4236/aar.2016.51002

[25] Martins, I.J. (2016) Drug Therapy for Obesity with Anti-Aging Genes Modification. Annals of Obesity and Disorders, 1, 1-4.

[26] Maier, J.A. (2003) Low Magnesium and Atherosclerosis: An Evidence-Based Link. Molecular Aspects of Medicine, 24, 137-146. http://dx.doi.org/10.1016/S0098-2997(02)00095-X

[27] Bo, S. and Pisu, E. (2008) Role of Dietary Magnesium in Cardiovascular Disease Prevention, Insulin Sensitivity and Diabetes. Current Opinion in Lipidology, 19, 50-56. http://dx.doi.org/10.1097/MOL.0b013e3282f33ccc

[28] Maxwell, S. (1999) Emergency Management of Acute Myocardial Infarction. British Journal of Clinical Pharmacology, 48, 284-298. http://dx.doi.org/10.1046/j.1365-2125.1999.00998.x

[29] Yilmaz, A., Yalta, K., Turgut, O.O., Yilmaz, M.B., Ozyol, A. and Kendirlioglu, O. (2006) Clinical Importance of Elevated CK-MB and Troponin I Levels in Congestive Heart Failure. Advances in Therapy, 23, 1060-1067. http://dx.doi.org/10.1007/BF02850226

[30] Zhou, Q. and Liao, J.K. (2009) Statins and Cardiovascular Diseases: From Cholesterol Lowering to Pleiotropy. Current Pharmaceutical Design, 15, 467-478. http://dx.doi.org/10.2174/138161209787315684

[31] Höglund, K., Wallin, A. and Blennow, K. (2006) Effect of Statins on Beta-Amyloid Metabolism in Humans: Potential Importance for the Development of Senile Plaques in Alzheimer's Disease. Acta Neurology Scandinavia Supplement, 185, 87-92. http://dx.doi.org/10.1111/j.1600-0404.2006.00691.x

[32] Lim, S.Y. (2013) Role of Statins in Coronary Artery Disease. Chonnam Medical Journal, 49, 1-6. http://dx.doi.org/10.4068/cmj.2013.49.1.1

[33] Touitou, Y., Touitou, C., Bogdan, A., Beck, H. and Reinberg, A. (1978) Serum Magnesium Circadian Rhythm in Human Adults with Respect to Age, Sex and Mental Status. Clinica Chimica Acta, 87, 35-41. http://dx.doi.org/10.1016/0009-8981(78)90054-2

[34] Martins, I.J. (2014) The Global Obesity Epidemic Is Related to Stroke, Dementia and Alzheimer's Disease. JSM Alzheimer's Disease Related Dementia, 1, 1010-1018.

[35] Saver, J.L., Starkman, S., Eckstein, M., Stratton, S.J., Pratt, F.D., Hamilton, S., et al. (2015) Prehospital Use of Magnesium Sulfate as Neuroprotection in Acute Stroke. New England Journal of Medicine, 372, 528-536. http://dx.doi.org/10.1056/NEJMoa1408827

[36] Cojocaru, I.M., Cojocaru, M., Burcin. C. and Atanasiu, N.A. (2007) Serum Magnesium in Patients with Acute Ischemic Stroke. Romanian Journal Internal Medicine, 45, 269-273.

[37] Harpreet, S., Jalodia, S., Gupta, M.S., Talapatra, P., Gupta, V. and Singh, I. (2012) Role of Magnesium Sulfate in Neuroprotection in Acute Ischemic Stroke. Annals of Indian Academy of Neurology, 15, 177-180. http://dx.doi.org/10.4103/0972-2327.99705

[38] Karandish, M., Tamimi, M., Shayesteh, A.A., Haghighizadeh, M.H. and Jalali, M.T. (2013) The Effect of Magnesium Supplementation and Weight Loss on Liver Enzymes in Patients with Nonalcoholic Fatty Liver Disease. Journal of Research Medical Science, 18, 573-579.

[39] Martins, I.J. (2013) Increased Risk for Obesity and Diabetes with Neurodegeneration in Developing Countries. Journal of Molecular and Genetic Medicine, S1, 001.

[40] Martins, I.J. (2014) Induction of NAFLD with Increased Risk of Obesity and Chronic Diseases in Developed Countries. Open Journal of Endocrine and Metabolic Diseases, 4, 90-110. http://dx.doi.org/10.4236/ojemd.2014.44011

[41] Martins, I.J. and Creegan, R. (2014) Links between Insulin Resistance, Lipoprotein Metabolism and Amyloidosis in Alzheimer's Disease. Health, 6, 1549-1579. http://dx.doi.org/10.4236/health.2014.612190

[42] Paolisso, G., Scheen, A., D’Onofrio, F. and Lefèbvre, P. (1990) Magnesium and Glucose Homeostasis. Diabetologia, 33, 511-514. http://dx.doi.org/10.1007/BF00404136

[43] Kandeel, F.R., Balon, E., Scott, S. and Nadler, J.L. (1996) Magnesium Deficiency and Glucose Metabolism in Rat Adipocytes. Metabolism, 45, 838-843. http://dx.doi.org/10.1016/S0026-0495(96)90156-0 
[44] Sales, C.H., Pedrosa, L.F., Lima, J.G., Lemos, T.M. and Colli, C. (2011) Influence of Magnesium Status and Magnesium Intake on the Blood Glucose Control in Patients with Type 2 Diabetes. Clinical Nutrition, 30, 359-364. http://dx.doi.org/10.1016/j.clnu.2010.12.011

[45] Pham, P.C., Pham, P.M., Pham, S.V., Miller, J.M. and Pham, P.T. (2007) Hypomagnesemia in Patients with Type 2 Diabetes. Clinical Journal of American Society of Nephrology, 2, 366-373. http://dx.doi.org/10.2215/CJN.02960906

[46] Schick, V., Scheiber, J.A., Mooren, F.C., Turi, S., Ceyhan, G.O. and Schnekenburger, J. (2014) Effect of Magnesium Supplementation and Depletion on the Onset and Course of Acute Experimental Pancreatitis. Gut, 63, 1469-1480. http://dx.doi.org/10.1136/gutjnl-2012-304274

[47] Papazachariou, I.M., Martinez-Isla, A., Efthimiou, E., Williamson, R.C. and Girgis, S.I. (2000) Magnesium Deficiency in Patients with Chronic Pancreatitis Identified by an Intravenous Loading Test. Clinica Chimica Acta, 302, 145-154. http://dx.doi.org/10.1016/S0009-8981(00)00363-6

[48] Sartori, S.B., Whittle, N., Hetzenauer, A. and Singewald, N. (2012) Magnesium Deficiency Induces Anxiety and HPA Axis Dysregulation: Modulation by Therapeutic Drug Treatment. Neuropharmacology, 62, 304-312. http://dx.doi.org/10.1016/j.neuropharm.2011.07.027

[49] Morris, M.E. (1992) Brain and CSF Magnesium Concentrations during Magnesium Deficit in Animals and Humans: Neurological Symptoms. Magnesium Research, 5, 303-313.

[50] Pochwat, B., Sowa-Kucma, M., Kotarska, K., Misztak, P., Nowak, G. and Szewczyk, B. (2015) Antidepressant-Like Activity of Magnesium in the Olfactory Bulbectomy Model Is Associated with the AMPA/BDNF Pathway. Psychopharmacology (Berl), 232, 355-367. http://dx.doi.org/10.1007/s00213-014-3671-6

[51] Durlach, J., Bac, P., Durlach, V., Bara, M. and Guiet-Bara, A. (1997) Neurotic, Neuromuscular and Autonomic Nervous Form of Magnesium Imbalance. Magnesium Research, 10, 169-195.

[52] Kirov, G.K. and Tsachev, K.N. (1990) Magnesium, Schizophrenia and Manic-Depressive Disease. Neuropsychobiology, 23, 79-81. http://dx.doi.org/10.1159/000119431

[53] de Baaij, J.H., Hoenderop, J.G. and Bindels, R.J. (2012) Regulation of Magnesium Balance: Lessons Learned from Human Genetic Disease. Clinical Kidney Journal, 5, i15-i24. http://dx.doi.org/10.1093/ndtplus/sfr164

[54] McCaughey, S.A. and Tordoff, M.G. (2002) Magnesium Appetite in the Rat. Appetite, 38, 29-38. http://dx.doi.org/10.1006/appe.2001.0443

[55] Sales, C.H., Santos, A.R., Cintra, D.E. and Colli, C. (2014) Magnesium-Deficient High-Fat Diet: Effects on Adiposity, Lipid Profile and Insulin Sensitivity in Growing Rats. Clinical Nutrition, 33, 879-888. http://dx.doi.org/10.1016/j.clnu.2013.10.004

[56] Nielsen, F.H. (2009) Dietary Fatty Acid Composition Alters Magnesium Metabolism, Distribution, and Marginal Deficiency Response in Rats. Magnesium Research, 22, 280-288.

[57] Ribeiro, M.C., Avila, D.S., Barbosa, N.B., Meinerz, D.F., Waczuk, E.P. and Hassan, W. (2013) Hydrochlorothiazide and High-Fat Diets Reduce Plasma Magnesium Levels and Increase Hepatic Oxidative Stress in Rats. Magnesium Research, 26, 32-40.

[58] Rayssiguier, Y., Gueux, E. and Weiser, D. (1981) Effect of Magnesium Deficiency on Lipid Metabolism in Rats Fed a High Carbohydrate Diet. Journal of Nutrition, 111, 1876-1883.

[59] Stamatelopoulos, K., Sibbing, D., Rallidis, L.S., Georgiopoulos, G., Stakos, D. and Braun, S. (2015) Amyloid-Beta $(1-40)$ and the Risk of Death from Cardiovascular Causes in Patients with Coronary Heart Disease. Journal of American College of Cardiology, 65, 904-916. http://dx.doi.org/10.1016/j.jacc.2014.12.035

[60] Williams, B. (2015) Amyloid Beta and Cardiovascular Disease: Intriguing Questions Indeed. Journal of American College of Cardiology, 65, 917-919. http://dx.doi.org/10.1016/j.jacc.2015.01.013

[61] Bates, K.A., Sohrabi, H.R., Rodrigues, M., Beilby, J., Dhaliwal, S.S. and Taddei, K. (2009) Association of Cardiovascular Factors and Alzheimer's Disease Plasma Amyloid-beta Protein in Subjective Memory Complainers. Journal of Alzheimer's Disease, 17, 305-318.

[62] Libby, P. (2006) Inflammation and Cardiovascular Disease Mechanisms. American Journal of Clinical Nutrition, 83, 456S-460S.

[63] Martins, I.J. (2015) Overnutrition Determines LPS Regulation of Mycotoxin Induced Neurotoxicity in Neurodegenerative Diseases. International Journal of Molecular Science, 16, 29554-29573. http://dx.doi.org/10.3390/ijms161226190

[64] Martins, I.J. (2015) Unhealthy Diets Determine Benign or Toxic Amyloid Beta States and Promote Brain Amyloid Beta Aggregation. Austin Journal of Clinical Neurology, 2, 1060-1066.

[65] Martins, I.J. (2015) Diabetes and Cholesterol Dyshomeostasis Involve Abnormal $\alpha$-Synuclein and Amyloid Beta Transport in Neurodegenerative Diseases. Austin Alzheimer's Journal of Parkinson's Disease, 2, 1020-1028.

[66] Martins, I.J. (2015) LPS Regulates Apolipoprotein E and A $\beta$ Interactions with Effects on Acute Phase Proteins and 
Amyloidosis. Advances in Aging Research, 4, 69-77. http://dx.doi.org/10.4236/aar.2015.42009

[67] Masters, C.L., Simms, G., Weinman, N.A., Multhaup, G., McDonald, B.L. and Beyreuther, K. (1985) Amyloid Plaque core Protein in Alzheimer's Disease and Down Syndrome. Proceedings of the National Academy of Sciences of the United States of America, 82, 4245-4249. http://dx.doi.org/10.1073/pnas.82.12.4245

[68] Bodovitz, S. and Klein, W.L. (1996) Cholesterol Modulates $\alpha$-Secretase Cleavage of Amyloid Precursor Protein. Journal of Biological Chemistry, 271, 4436-4440. http://dx.doi.org/10.1074/jbc.271.8.4436

[69] Vassar, R., Bennett, B.D., Babu-Khan, S., Kahn, E., Mendiaz, A. and Denis, P. (1999) Beta-Secretase Cleavage of Alzheimer’s Amyloid Precursor Protein by the Trans-Membrane Aspartic Protease BACE. Science, 286, 735-741. http://dx.doi.org/10.1126/science.286.5440.735

[70] Esch, F.S., Keim, P.S., Beattie, E.C., Blacher, R.W., Culwell, A.R. and Oltersdorf, T. (1990) Cleavage of Amyloid Beta Peptide during Constitutive Processing of Its Precursor. Science, 248, 1122-1124. http://dx.doi.org/10.1126/science.2111583

[71] Soriano, S., Chyung, A.S., Chen, X., Stokin, G.B., Lee, V.N. and Koo, E.H. (1999) Expression of $\beta$-Amyloid Precursor Protein-CD3 $\gamma$ Chimeras to Demonstrate the Selective Ge-Neration of Amyloid $\beta_{1-40}$ and Amyloid $\beta_{1-42}$ Peptides within Secretory and Endocytic Compartments. Journal of Biological Chemistry, 274, 32295-32300. http://dx.doi.org/10.1074/jbc.274.45.32295

[72] Martins, I.J., Gupta, V., Wilson, A.C., Fuller, S.J. and Martins, R.N. (2014) Interactions between ApoE and Amyloid Beta and Their Relationship to Nutriproteomics and Neurodegeneration. Current Proteomics, 11, 173-183.

[73] Nassir, F., Mazur, A., Giannoni, F., Gueux, E., Davidson, N.O. and Rayssiguier, Y. (1995) Magnesium Deficiency Modulates Hepatic Lipogenesis and Apolipoprotein Gene Expression in the Rat. Biochimica Biophysica Acta, 1257, 125-132. http://dx.doi.org/10.1016/0005-2760(95)00065-K

[74] Ravn, H.B., Korsholm, T.L. and Falk, E. (2001) Oral Magnesium Supplementation Induces Favorable Antiatherogenic Changes in ApoE-Deficient Mice. Arteriosclerosis, Thrombosis Vascular Biology, 21, 858-862. http://dx.doi.org/10.1080/07315724.2007.10719593

[75] Olatunji, L.A. and Soladoye, A.O. (2007) Effect of Increased Magnesium Intake on Plasma Cholesterol, Triglyceride and Oxidative Stress in Alloxan-Diabetic Rats. African Journal of Medical Science, 36, 155-161.

[76] Zhou, Q., Mahfouz, M.M. and Kummerow, F.A. (1994) Effect of Dietary Magnesium Deficiency with/without Cholesterol Supplementation on Phospholipid Content in Liver, Plasma and Erythrocytes of Rabbits. Magnesium Research, 7, 23-30.

[77] Nielsen, F.H., Milne, D.B., Klevay, L.M., Gallagher, S. and Johnson, L. (2007) Dietary Magnesium Deficiency Induces Heart Rhythm Changes, Impairs Glucose Tolerance, and Decreases Serum Cholesterol in Post Menopausal Women. Journal of American College of Nutrition, 26, 121-132. http://dx.doi.org/10.1080/07315724.2007.10719593

[78] Martins, I.J. and Fernando, W. (2014) High Fibre Diets and Alzheimer’s Disease. Food and Nutrition Sciences, 5, 410424. http://dx.doi.org/10.4236/fns.2014.54049

[79] Hayashi, H., Kimura, N., Yamagauchi, H., Hasegawa, K., Yokoseki, T. and Shibata, M. (2004) A Seed for Alz-Heimer Amyloid in the Brain. Journal of Neuroscience, 24, 4894-4902.

http://dx.doi.org/10.1523/JNEUROSCI.0861-04.2004

[80] Bieschke, J., Zhang, Q., Powers, E.T., Lerner, R.A. and Kelly, J.W. (2005) Oxidative Metabolites Accelerate Alzheimer's Amyloidogenesis by a Two Step Mechanism, Eliminating the Requirement for Nucleation. Biochemistry, 44, 4977-4983. http://dx.doi.org/10.1021/bi0501030

[81] Yu, J., Sun, M., Chen, Z., Lu, J., Liu, Y. and Zhou, L. (2010) Magnesium Modulates Amyloid-Beta Protein Precursor Trafficking and Processing. Journal of Alzheimer's Disease, 20, 1091-1106.

[82] Van Den Heuvel, C., Finnie, J.W., Blumbergs, P.C., Manavis, J., Jones, N.R. and Reilly, P.L. (2000) Upregulation of Neuronal Amyloid Precursor Protein (APP) and APP mRNA Following Magnesium Sulphate $\left(\mathrm{MgSO}_{4}\right)$ Therapy in Traumatic Brain Injury. Journal of Neurotrauma, 17, 1041-1053. http://dx.doi.org/10.1089/neu.2000.17.1041

[83] Yu, X., Guan, P.-P., Guo, J.-W., Wang, Y., Cao, L.-L. and Xu, G.-B. (2015) By Suppressing the Expression of Anterior Pharynx-Defective- $1 \alpha$ and $-1 \beta$ and Inhibiting the Aggregation of $\beta$-Amyloid Protein, Magnesium Ions Inhibit the Cognitivedecline of Amyloid Precursor Protein/Presenilin 1 Trans-Genic Mice. FASEB Journal, 29, 5044-5058. http://dx.doi.org/10.1096/fj.15-275578

[84] Li, W., Yu, J., Liu, Y., Huang, X., Abumaria, N. and Zhu, Y. (2013) Elevation of Brain Magnesium Prevents and Reverses Cognitive Deficits and Synaptic Loss in Alzheimer's Disease Mouse Model. Journal of Neuroscience, 33, 84238441. http://dx.doi.org/10.1523/JNEUROSCI.4610-12.2013

[85] Xu, Z.P., Li, L., Bao, J., Wang, Z.H., Zeng, J. and Liu, E.J. (2014) Magnesium Protects Cognitive Functions and Synaptic Plasticity in Streptozotocin-Induced Sporadic Alzheimer's Model. PLoS ONE, 9, e108645. http://dx.doi.org/10.1371/journal.pone.0108645 
[86] Altura, B.M., Shah, N.C., Shah, G.J., Li, W., Zhang, A. and Zheng, T. (2013) Magnesium Deficiency Upregulates Sphingomyelinases in Cardiovascular Tissues and Cells: Cross-Talk among Proto-Oncogenes, $\mathrm{Mg}^{2+}$, NF- $\kappa \mathrm{B}$ and Ceramide and Their Potential Relationships to Resistant Hypertension, Atherogenesis and Cardiac Failure. International Journal of Clinical Experimental Medicine, 6, 861-879.

[87] Altura, B.M., Shah, N.C., Shah, G., Zhang, A., Li, W., Zheng, T., Perez-Albela, J.L., et al. (2012) Short-Term Magnesium Deficiency Upregulates Ceramide Synthase in Cardiovascular Tissues and Cells: Cross-Talk among Cytokines, $\mathrm{Mg}^{2+}$, NF- $\kappa \mathrm{B}$, and de Novo Ceramide. American Journal Physiology Heart Circulation Physiology, 302, H319-H332. http://dx.doi.org/10.1152/ajpheart.00453.2011

[88] Radhakrishnan, J., Remuzzi, G., Saran, R., Williams, D.E., Rios-Burrows, N. and Powe, N. (2014) Taming the Chronic Kidney Disease Epidemic: A Global View of Surveillance Efforts. Kidney International, 86, 246-250. http://dx.doi.org/10.1038/ki.2014.190

[89] Coskuner, O. and Murray, I.V. (2014) Adenosine Triphosphate (ATP) Reduces Amyloid- $\beta$ Protein Misfolding in Vitro. Journal of Alzheimer's Disease, 41, 561-574.

[90] Schmidt, C., Lepsverdize, E., Chi, S.L., Das, A.M., Pizzo, S.V., Dityatev, A. and Schachner, M. (2008) Amyloid Precursor Protein and Amyloid Beta-Peptide Bind to ATP Synthase and Regulate Its Activity at the Surface of Neural Cells. Molecular Psychiatry, 13, 953-969. http://dx.doi.org/10.1038/sj.mp.4002077

[91] Ko, Y.H., Hong, S. and Pedersen, P.L. (1999) Chemical Mechanism of ATP Synthase. Magnesium Plays a Pivotal Role in Formation of the Transition State Where ATP Is Synthesized from ADP and Inorganic Phosphate. Journal of Biological Chemistry, 274, 28853-28856. http://dx.doi.org/10.1074/jbc.274.41.28853

[92] Fox, C., Ramsoomair, D. and Carter, C. (2001) Magnesium: Its Proven and Potential Clinical Significance. South Medical Journal, 94, 1195-1201. http://dx.doi.org/10.1097/00007611-200112000-00013

[93] Kubota, T., Shindo, Y., Tokuno, K., Komatsu, H., Ogawa, H. and Kudo, S. (2005) Mitochondria Are Intracellular Magnesium Stores: Investigation by Simultaneous Fluorescent Imagings in PC12 Cells. Biochimica Biophysica Acta, 15, 19-28. http://dx.doi.org/10.1016/j.bbamcr.2004.10.013

[94] Shah, N.C., Shah, G.J., Li, Z., Jiang, X.C., Altura, B.T. and Altura, B.M. (2014) Short-Term Magnesium Deficiency Downregulates Telomerase, Upregulates Neutral Sphingomyelinase and Induces Oxidative DNA Damage in Cardiovascular Tissues: Relevance to Atherogenesis, Cardiovascular Diseases and Aging. International Journal of Clinical Experimental Medicine, 7, 497-514.

[95] Zhang, B., Chen, J., Cheng, A.S. and KO, B.C. (2014) Depletion of Sirtuin 1 (SIRT1) Leads to Epigenetic Modifications of Telomerase (TERT) Gene in Hepatocellular Carcinoma Cells. PLoS ONE, 9, e84931. http://dx.doi.org/10.1371/journal.pone.0084931

[96] Palacios, J.A., Herranz, D., De Bonis, M.L., Velasco, S., Serrano, M. and Blasco, M.A. (2010) SIRT1 Contributes to Telomere Maintenance and Augments Global Homologous Recombination. Journal of Cell Biology, 191, 1299-1313. http://dx.doi.org/10.1083/jcb.201005160

[97] Draper, D.E. (2004) A Guide to Ions and RNA Structure. RNA, 10, 335-343. http://dx.doi.org/10.1261/rna.5205404

[98] Misra, V.K. and Draper, D.E. (1998) On the Role of Magnesium Ions in RNA Stability. Biopolymers, 48, 113-135. http://dx.doi.org/10.1002/(SICI)1097-0282(1998)48:2<113::AID-BIP3>3.0.CO;2-Y

[99] Serra, M.J., Baird, J.D., Dale, T., Fey, B.L., Retatagos, K. and Westhof, E. (2002) Effects of Magnesium Ions on the Stabilization of RNA Oligomers of Defined Structures. RNA, 8, 307-323. http://dx.doi.org/10.1017/S1355838202024226

[100] Hartwig, A. (2001) Role of Magnesium in Genomic Stability. Mutation Research, 475, 113-121. http://dx.doi.org/10.1016/S0027-5107(01)00074-4

[101] Littlefield, N.A., Hass, B.S., James, S.J. and Poirier, L.A. (1994) Protective Effect of Magnesium on DNA Strand Breaks Induced by Nickel or Cadmium. Cell Biology Toxicology, 10, 127-135. http://dx.doi.org/10.1007/BF00756493

[102] Xue, Y., Wang, S. and Feng, X. (2009) Influence of Magnesium Ion on the Binding of p53 DNA-Binding Domain to DNA-Response Elements. Journal of Biochemistry, 146, 77-85. http://dx.doi.org/10.1093/jb/mvp048

[103] Matsusaka, H., Ide, T., Matsushima, S., Ikeuchi, M., Kubota, T. and Sunagawa, K. (2006) Targeted Deletion of p53 Prevents Cardiac Rupture after Myocardial Infarction in Mice. Cardiovascular Research, 70, 457-465. http://dx.doi.org/10.1016/j.cardiores.2006.02.001

[104] Zhang, Y., Köhler, K., Xu, J., Lu, D., Braun, T. and Schlitt, A. (2011) Inhibition of p53 after Acute Myocardial Infarction: Reduction of Apoptosis Is Counteracted by Disturbed Scar Formation and Cardiac Rupture. Journal of Molecular Cell Cardiology, 50, 471-478. http://dx.doi.org/10.1016/j.yjmcc.2010.11.006

[105] McAlindon, E., Bucciarelli-Ducci, C., Suleiman, M.S. and Baumbach, A. (2015) Infarct Size Reduction in Acute Myocardial Infarction. Heart, 101, 155-160. http://dx.doi.org/10.1136/heartjnl-2013-304289

[106] Chong, Z.Z., Wang, S., Shang, Y.C. and Maiese, K. (2102) Targeting Cardiovascular Disease with Novel SIRT1 Path- 
ways. Future Cardiology, 8, 89-100. http://dx.doi.org/10.2217/fca.11.76

[107] Shimoyama, Y., Mitsuda, Y., Tsuruta, Y., Suzuki, K., Hamajima, N. and Niwa, T. (2012) SIRTUIN 1 Gene Polymorphisms Are Associated with Cholesterol Metabolism and Coronary Artery Calcification in Japanese Hemodialysis Patients. Journal of Renal Nutrition, 22, 114-119. http://dx.doi.org/10.1053/j.jrn.2011.10.025

[108] Winnik, S., Auwerx, J., Sinclair, D.A. and Matter, C.M. (2015) Protective Effects of Sirtuins in Cardiovascular Diseases: From Bench to Bedside. European Heart Journal, 36, 3404-3412. http://dx.doi.org/10.1093/eurheartj/ehv290

[109] Stanika, R.I., Winters, C.A., Pivovarova, N.B. and Andrews, S.B. (2010) Differential NMDA Receptor-Dependent Calcium Loading and Mitochondrial Dysfunction in CA1 vs. CA3 Hippocampal Neurons. Neurobiology Disease, 37, 403-411. http://dx.doi.org/10.1016/j.nbd.2009.10.020

[110] Peng, T.I., Jou, M.J., Sheu, S.S. and Greenamyre, J.T. (1998) Visualization of NMDA Receptor-Induced Mitochondrial Calcium Accumulation in Striatal Neurons. Experimental Neurology, 149, 1-12. http://dx.doi.org/10.1006/exnr.1997.6599

[111] Poleszak, E., Wlaź, P., Wróbel, A., Fidecka, S. and Nowak, G. (2008) NMDA/Glutamate Mechanism of MagnesiumInduced Anxiolytic-Like Behavior in Mice. Pharmacology Reports, 60, 665-663.

[112] Poulaki, V., Benekou, A., Bozas, E., Bolaris, S. and Stylianopoulou, F. (1999) p53 Expression and Regulation by NMDA Receptors in the Developing Rat Brain. Journal of Neuroscience Research, 56, 427-440. http://dx.doi.org/10.1002/(SICI)1097-4547(19990515)56:4<427::AID-JNR10>3.0.CO;2-J

[113] Michán, S., Li, Y., Chou, M.M., Parrella, E., Ge, H. and Long, J.M. (2010) SIRT1 Is Essential for Normal Cognitive Function and Synaptic Plasticity. Journal of Neuroscience, 30, 9695-9707. http://dx.doi.org/10.1523/JNEUROSCI.0027-10.2010

[114] Martins, I.J. (2015) Nutritional Diets Accelerate Amyloid Beta Metabolism and Prevent the Induction of Chronic Diseases and Alzheimer's Disease. Photon eBooks, 1-48.

[115] Howard, A.B., Alexander, R.W. and Taylor, W.R. (1995) Effects of Magnesium on Nitric Oxide Synthase Activity in Endothelial Cells. American Journal of Physiology, 269, C612-C618.

[116] Pearson, P.J., Evora, P.R., Seccombe, J.F. and Schaff, H.V. (1998) Hypomagnesemia Inhibits Nitric Oxide Release from Coronary Endothelium: Protective Role of Magnesium Infusion after Cardiac Operations. Annals of Thoracic Surgery, 65, 967-972. http://dx.doi.org/10.1016/S0003-4975(98)00020-4

[117] Teragawa, H., Kato, M., Yamagata, T., Matsuura, H. and Kajiyama, G. (2001) Magnesium Causes Nitric Oxide Independent Coronary Artery Vasodilation in Humans. Heart, 86, 212-216. http://dx.doi.org/10.1136/heart.86.2.212

[118] Finckenberg, P., Merasto, S., Louhelainen, M., Lindgren, L., Vapaatalo, H. and Müller, D.N. (2005) Magnesium Supplementation Prevents Angiotensin II-Induced Myocardial Damage and CTGF Overexpression. Journal of Hypertension, 23, 375-380.

[119] Sapna, S., Ranjith, S.K. and Shivakumar, K. (2006) Cardiac Fibrogenesis in Magnesium Deficiency: A Role for Circulating Angiotensin II and Aldosterone. American Journal of Physiology Heart Circulation Physiology, 291, H436H440. http://dx.doi.org/10.1152/ajpheart.01185.2005

[120] Dai, T., Ramirez-Correa, G. and Gao, W.D. (2006) Apelin Increases Contractility in Failing Cardiac Muscle. European Journal of Cardiology, 553, 222-228. http://dx.doi.org/10.1016/j.ejphar.2006.09.034

[121] Ichihara, A., Suzuki, H. and Saruta, T. (1993) Effects of Magnesium on the Renin-Angiotensin-Aldosterone System in Human Subjects. Journal of Laboratory Clinical Medicine, 122, 432-440.

[122] Sipes, S.L., Weiner, C.P., Gellhaus, T.M. and Goodspeed, J.D. (1989) The Plasma Renin-Angiotensin System in Preeclampsia: Effects of Magnesium Sulfate. Obstetrics Gynecology, 73, 934-937.

[123] Touyz, R.M. and Schiffrin, E.L. (1993) The Effect of Angiotensin II on Platelet Intracellular Free Magnesium and Calcium Ionic Concentrations in Essential Hypertension. Journal of Hypertension, 11, 551-558. http://dx.doi.org/10.1097/00004872-199305000-00011

[124] Herencia, C., Rodríguez-Ortiz, M.E., Muñoz-Castañeda, J.R., Martinez-Moreno, J.M., Canalejo, R. and Montes de Oca, A. (2015) Angiotensin II Prevents Calcification in Vascular Smooth Muscle Cells by Enhancing Magnesium Influx. European Journal of Clinical Investigation, 45, 1129-1144. http://dx.doi.org/10.1111/eci.12517

[125] Agus, Z.S., Kelepouris, E., Dukes, I. And Morad, M. (1989) Cytosolic Magnesium Modulates Calcium Channel Activity in Mammalian Ventricular Cells. American Journal of Physiology, 256, C452-C455.

[126] Paunier, L. (1992) Effect of Magnesium on Phosphorus and Calcium Metabolism. Monatsschr Kinderheilkd, 140, S17S20.

[127] Dai, Q., Motley, S.S., Smith, J.A., Concepcion, R., Barocas, D., Byerly, S., et al. (2011) Blood Magnesium, and the Interaction with Calcium, on the Risk of High-Grade Prostate Cancer. PLoS ONE, 6, e18237. http://dx.doi.org/10.1371/journal.pone.0018237 
[128] Babich, M.F. and Kalin, M.L. (1989) Calcium-Channel Blockers in Acute Myocardial Infarction. Drug Intelligence and Clinical Pharmacology, 23, 538-547.

[129] Wang, C., Liu, N., Luan, R., Li, Y., Wang, D. and Zou, W. (2013) Apelin Protects Sarcoplasmic Reticulum Function and Cardiac Performance in Ischaemia-Reperfusion by Attenuating Oxidation of Sarcoplasmic Reticulum $\mathrm{Ca}^{2+}$ ATPase and Ryanodine Receptor. Cardiovascular Research, 100, 114-124. http://dx.doi.org/10.1093/cvr/cvt160

[130] Markaki, A., Kyriazis, J., Stylianou, K., Fragkiadakis, G.A., Perakis, K. and Margioris, A.N. (2012) The Role of Serum Magnesium and Calcium on the Association between Adiponectin Levels and All-Cause Mortality in End-Stage Renal Disease Patients. PLoS ONE, 7, e52350. http://dx.doi.org/10.1371/journal.pone.0052350

[131] Cassidy, A., Skidmore, P., Rimm, E.B., Welch, A., Fairweather-Tait, S. and Skinner, J. (2009) Plasma Adiponectin Concentrations Are Associated with Body Composition and Plant-Based Dietary Factors in Female Twins. Journal of Nutrition, 139, 353-358. http://dx.doi.org/10.3945/jn.108.098681

[132] Toth, P.P. (2005) Adiponectin and High-Density Lipoprotein: A Metabolic Association through Thick and Thin. European Heart Journal, 26, 1579-1581. http://dx.doi.org/10.1093/eurheartj/ehi374

[133] Pischon, T., Girman, C.J., Hotamisligil, G.S., Rifai, N., Hu, F.B. and Rimm, E.B. (2004) Plasma Adiponectin Levels and Risk of Myocardial Infarction in Men. JAMA, 291, 1730-1737. http://dx.doi.org/10.1001/jama.291.14.1730

[134] Teoh, H., Strauss, M.H., Szmitko, P.E. and Verma, S. (2006) Adiponectin and Myocardial Infarction: A Paradox or a Paradigm? European Heart Journal, 27, 2266-2268. http://dx.doi.org/10.1093/eurheartj/ehl248

[135] Banga, A., Bodles, A.M., Rasouli, N., Ranganathan, G., Kern, P.A. and Owens, R.J. (2008) Calcium Is Involved in Formation of High Molecular Weight Adiponectin. Metabolic Syndrome Related Disorders, 6, 103-111. http://dx.doi.org/10.1089/met.2007.0033

[136] Henstridge, D.C. and Febbraio, M.A. (2010) Adiponectin Sparks an Interest in Calcium. Cell Metabolism, 11, 447-449. http://dx.doi.org/10.1016/j.cmet.2010.05.007

[137] Wu, Q., Zheng, R., Srisai, D., McKnight, G.S. and Palmiter, R.D. (2013) NR2B Subunit of the NMDA Glutamate Receptor Regulates Appetite in the Parabrachial Nucleus. Proceedings of the National Academy of Sciences of the United States of America, 110, 14765-14770. http://dx.doi.org/10.1073/pnas.1314137110

[138] Xu, C., Bai, B., Fan, P., Cai, Y., Huang, B. and Law, I.K. (2013) Selective Overexpression of Human SIRT1 in Adipose Tissue Enhances Energy Homeostasis and Prevents the Deterioration of Insulin Sensitivity with Ageing in Mice. American Journal Translational Research, 5, 412-426.

[139] Choi, Y., Um, S.J. and Park, T. (2013) Indole-3-Carbinol Directly Targets SIRT1 to Inhibit Adipocyte Differentiation. International Journal of Obesity (London), 37, 881-884. http://dx.doi.org/10.1038/ijo.2012.158

[140] Siersbaek, R., Nielsen, R. and Mandrup, S. (2010) PPAR Gamma in Adipocyte Differentiation and MetabolismNovel Insights from Genome-Wide Studies. FEBS Journal, 584, 3242-3249.

http://dx.doi.org/10.1016/j.febslet.2010.06.010

[141] Körner, A., Wabitsch, M., Seidel, B., Fischer-Posovszky, P., Berthold, A., Stumvoll, M., et al. (2005) Adiponectin Expression in Humans Is Dependent on Differentiation of Adipocytes and Down-Regulated by Humoral Serum Components of High Molecular Weight. Biochemistyr Biophysica Research Communications, 337, 540-550. http://dx.doi.org/10.1016/j.bbrc.2005.09.064

[142] Lee, M.J., Wu, Y. and Fried, S.K. (2010) Adipose Tissue Remodeling in Pathophysiology of Obesity. Current Opinion Clinical Nutrition and Metabolic Care, 13, 371-376. http://dx.doi.org/10.1097/MCO.0b013e32833aabef

[143] Qiao, L. and Shao, J. (2006) SIRT1 Regulates Adiponectin Gene Expression through Foxo1-C/Enhancer-Binding Protein Alpha Transcriptional Complex. Journal of Biological Chemistry, 281, 39915-39924. http://dx.doi.org/10.1074/jbc.M607215200

[144] Qiang, L., Wang, H. and Farmer, S.R. (2007) Adiponectin Secretion Is Regulated by SIRT1 and the Endoplasmic Reticulum Oxidoreductase Ero1-L Alpha. Molecular Cellular Biology, 27, 4698-4707. http://dx.doi.org/10.1128/MCB.02279-06

[145] Shen, Z., Liang, X., Rogers, C.Q., Rideout, D. and You, M. (2010) Involvement of Adiponectin-SIRT1-AMPK Signaling in the Protective Action of Rosiglitazone against Alcoholic Fatty Liver in Mice. American Journal of Physiology and Gastrointestinal Liver Physiology, 298, G364-G374. http://dx.doi.org/10.1152/ajpgi.00456.2009

[146] Lancaster, G.I. and Febbraio, M.A. (2011) Adiponectin Sphings into Action. Nature Medicine, 17, 37-38. http://dx.doi.org/10.1038/nm0111-37

[147] Samad, F., Badeanlou, L., Shah, C. and Yang, G. (2011) Adipose Tissue and Ceramide Biosynthesis in the Pathogenesis of Obesity. In: Cowart, L.A., Eds., Sphingolipids and Metabolic Disease, Springer, New York, 67-86. http://dx.doi.org/10.1007/978-1-4614-0650-1_5

[148] Błachnio-Zabielska, A.U., Pułka, M., Baranowski, M., Nikołajuk, A., Zabielski, P. and Górska, M. (2012) Ceramide 
Metabolism Is Affected by Obesity and Diabetes in Human Adipose Tissue. Journal of Cellular Physiology, 227, 550557. http://dx.doi.org/10.1002/jcp.22745

[149] Matsuura, F., Oku, H., Koseki, M., Sandoval, J.C., Yuasa-Kawase, M. and Tsubakio-Yamamoto, K. (2007) Adiponectin Accelerates Reverse Cholesterol Transport by Increasing High Density Lipoprotein Assembly in the Liver. Biochemical Biophysica Research Communications, 358, 1091-1095. http://dx.doi.org/10.1016/j.bbrc.2007.05.040

[150] Muradian, K. and Schachtschabel, D.O. (2001) The Role of Apoptosis in Aging and Age-Related Disease: Update. Zeitschrift für Gerontologie und Geriatrie, 34, 441-446. http://dx.doi.org/10.1007/s003910170015

[151] Sastre, J., Pallardó, F.V. and Viña, J. (2000) Mitochondrial Oxidative Stress Plays a Key Role in Aging and Apoptosis. IUBMB Life, 49, 427-435. http://dx.doi.org/10.1080/152165400410281

[152] Pollack, M. and Leeuwenburgh, C. (2001) Apoptosis and Aging: Role of the Mitochondria. Journals of Gerontology Series A: Biological Sciences and Medical Sciences, 56, B475-B482. http://dx.doi.org/10.1093/gerona/56.11.B475

[153] Takaya, J., Higashino, H. and Kobayashi, Y. (2004) Intracellular Magnesium and Insulin Resistance. Magnesium Research, 17, 126-136.

[154] Laires, M.J., Monteiro, C.P. and Bicho, M. (2004) Role of Cellular Magnesium in Health and Human Disease. Frontiers in Bioscience, 9, 262-276. http://dx.doi.org/10.2741/1223

[155] Turecky, L., Kupcova, V., Szantova, M., Uhlikova, E., Viktorinova, A. and Czirfusz, A. (2006) Serum Magnesium Levels in Patients with Alcoholic and Non-Alcoholic Fatty Liver. Bratislavské lekárske listy, 107, 58-61.

[156] Castiglioni, S. and Maier, J.A. (2011) Magnesium and Cancer: A Dangerous Liason. Magnesium Research, 24, S92S100.

[157] Brooks, C.L. and Gu, W. (2009) How Does SIRT1 Affect Metabolism, Senescence and Cancer? Nature Review Cancer, 9, 123-128. http://dx.doi.org/10.1038/nrc2562

[158] Fenton, M.J. and Golenbock, D.T. (1998) LPS-Binding Proteins and Receptors. Journal of Leukocyte Biology, 64, 2532.

[159] Asai, Y., Iwamoto, K. and Watanabe, S. (1998) The Effect of the Lipid a Analog E5531 on Phospholipid Membrane Properties. Federation of European Biochemical Societies Letters, 438, 15-20. http://dx.doi.org/10.1016/S0014-5793(98)01262-9

[160] Ciesielski, F., Griffin, D.C., Rittig, M., Moriyón, I. and Bonev, B.B. (2013) Interactions of Lipopolysaccharide with Lipid Membranes, Raft Models_-A Solid State NMR Study. Biochimica et Biophysica Acta (BBA)—Biomembranes, 1828, 1731-1742. http://dx.doi.org/10.1016/j.bbamem.2013.03.029

[161] Ciesielski, F., Davis, B., Rittig, M., Bonev, B.B. and O’Shea, P. (2012) Receptor-Independent Interaction of Bacterial Lipopolysaccharide with Lipid and Lymphocyte Membranes, the Role of Cholesterol. PLoS ONE, 7, e38677. http://dx.doi.org/10.1371/journal.pone.0038677

[162] Tam, M., Gómez, S., González-Gross, M. and Marcos, A. (2003) Possible Roles of Magnesium on the Immune System. European Journal of Clinical Nutrition, 57, 1193-1197. http://dx.doi.org/10.1038/sj.ejcn.1601689

[163] Geerlings, S.E. and Hoepelman, A.I. (1999) Immune Dysfunction in Patients with Diabetes Mellitus (DM). FEMS Immunology and Medical Microbiology, 26, 259-265. http://dx.doi.org/10.1111/j.1574-695X.1999.tb01397.x

[164] Casqueiro, J., Casqueiro, J. and Alves, C. (2012) Infections in Patients with Diabetes Mellitus: A Review of Pathogenesis. Indian Journal of Endocrinology and Metabolism, 16, 27-36. http://dx.doi.org/10.4103/2230-8210.94253

[165] Martinsm I.J., Vilchèze, C., Mortimer, B.C., Bittman, R. and Redgrave, T.G. (1998) Sterol Side Chain Length and Structure Affect the Clearance of Chylomicron-Like Lipid Emulsions in Rats and Mice. Journal Lipid Research, 39, 302-312.

[166] Dou, M., Ma, A.G., Wang, Q.Z., Liang, H., Li, Y., Yi, X.M., et al. (2009) Supplementation with Magnesium and Vitamin E Were More Effective than Magnesium Alone to Decrease Plasma Lipids and Blood Viscosity in Diabetic Rats. Nutrition Research, 29, 519-524. http://dx.doi.org/10.1016/j.nutres.2009.07.001

[167] Tongyai, S., Rayssiguier, Y., Motta, C., Gueux, E., Maurois, P. and Heaton, F.W. (1989) Mechanism of Increased Erythrocyte Membrane Fluidity during Magnesium Deficiency in Weanling Rats. American Journal of Physiology, 257, C270-C276.

[168] Stamatotos, L. and Silvius, J.R. (1987) Effects of Cholesterol on the Divalent Cation-Mediated Interactions of Vesicles Containing Amino and Choline Phospholipids. Biochimica et Biophysica Acta (BBA)—Biomembranes, 905, 81-90. http://dx.doi.org/10.1016/0005-2736(87)90011-3

[169] Desrumaux, C., Risold, P.Y., Schroeder, H., Deckert, V., Masson, D. and Athias, A. (2005) Phospholipid Transfer Protein (PLTP) Deficiency Reduces Brain Vitamin E Content and Increases Anxiety in Mice. FASEB Journal, 19, 296-297.

[170] Martins, I.J., Hopkins, L., Joll, C.A. and Redgrave, T.G. (1991) Interactions between Model Triacylglycerol-Rich 
Lipoproteins and High-Density Lipoproteins in Rat, Rabbit and Man. Biochimica et Biophysica Acta (BBA)—Lipids and Lipid Metabolism, 1081, 328-338. http://dx.doi.org/10.1016/0005-2760(91)90290-X

[171] Nishida, Y., Ito, S., Ohtsuki, S., Yamamoto, N., Takahashi, T., Iwata, N., et al. (2009) Depletion of Vitamin E Increases Amyloid Beta Accumulation by Decreasing Its Clearances from Brain and Blood in a Mouse Model of Alzheimer Disease. Journal of Biological Chemistry, 284, 33400-33408. http://dx.doi.org/10.1074/jbc.M109.054056

[172] Desrumaux, C., Pisoni, A., Meunier, J., Deckert, V., Athias, A. and Perrier, V. (2013) Increased Amyloid-Beta Peptide-Induced Memory Deficits in Phospholipid Transfer Protein (PLTP) Gene Knockout Mice. Neuropsychopharmacology, 38, 817-825. http://dx.doi.org/10.1038/npp.2012.247

[173] Muñoz, F.J., Solé, M. and Coma, M. (2005) The Protective Role of Vitamin E in Vascular Amyloid Beta-Mediated Damage. In: Harris, J.R. and Fahrenholz, F., Eds., Alzheimer's Disease, Springer, Berlin, 147-165. http://dx.doi.org/10.1007/0-387-23226-5_7

[174] Costa, M., Ortiz, A.M. and Jorquera, J.I. (2012) Therapeutic Albumin Binding to Remove Amyloid- $\beta$. Journal of Alzheimer's Disease, 29, 159-170.

[175] Bharrhan, S., Chopra, K. and Rishi, P. (2010) Vitamin E Supplementation Modulates Endotoxin-induced Liver Damage in a Rat Model. American Journal of Biomedical Sciences, 2, 51-62.

[176] Kroll, M.H. and Elin, R.J. (1985) Relationships between Magnesium and Protein Concentrations in Serum. Clinical Chemistry, 31, 244-246.

[177] Fein. P., Weiss, S., Ramos, F., Singh, P., Chattopadhyay, J. and Avram, M.M. (2014) Serum Magnesium Concentration Is a Significant Predictor of Mortality in Peritoneal Dialysis Patients. Advances in Peritoneal Dialysis, 30, 90-93.

[178] Ruot, B., Breuillé, D., Rambourdin, F., Bayle, G., Capitan, P. and Obled, C. (2000) Synthesis Rate of Plasma Albumin Is a Good Indicator of Liver Albumin Synthesis in Sepsis. American Journal Physiology Endocrinology Metabolism, 279, E244-E251.

[179] Wang, X., Li, W., Lu, J., Li, N. and Li, J. (2004) Lipopolysaccharide Suppresses Albumin Expression by Activating NF-KappaB in Rat Hepatocytes. Journal of Surgical Research, 122, 274-279. http://dx.doi.org/10.1016/j.jss.2004.07.008

[180] Don, B.R. and Kaysen, G. (2004) Serum Albumin: Relationship to Inflammation and Nutrition. Seminars in Dialysis, 17, 432-437. http://dx.doi.org/10.1111/j.0894-0959.2004.17603.x

[181] van der Vusse, G.J. (2009) Albumin as Fatty Acid Transporter. Drug Metabolism and Pharmacokinetics, 24, 300-307. http://dx.doi.org/10.2133/dmpk.24.300

[182] Charalambous, B.M., Stephens, R.C., Feavers, I.M. and Montgomery, H.E. (2007) Role of Bacterial Endotoxin in Chronic Heart Failure: The Gut of the Matter. Shock, 28, 15-23. http://dx.doi.org/10.1097/shk.0b013e318033ebc5

[183] Lew, W.Y. (2003) Endotoxin Attacks the Cardiovascular System: Black Death at the Tollgate. Journal of American College of Cardiology, 42, 1663-1665. http://dx.doi.org/10.1016/j.jacc.2003.08.006

[184] Okeke, I.N., Laxminarayan, R., Bhutta, Z.A., Duse, A.G., Jenkins, P., O’Brien, T.F., et al. (2005) Antimicrobial Resistance in Developing Countries. Part I: Recent Trends and Current Status. Lancet Infectious Diseases, 5, 481-493. http://dx.doi.org/10.1016/S1473-3099(05)70189-4

[185] Schäfer, T., Scheuer, C., Roemer, K., Menger, M.D. and Vollmar, B. (2003) Inhibition of p53 Protects Liver Tissue against Endotoxin-Induced Apoptotic and Necrotic Cell Death. FASEB Journal, 17, 660-667. http://dx.doi.org/10.1096/fj.02-0774com

[186] Laires, M.J. and Monteiro, C. (2008) Exercise, Magnesium and Immune Function. Magnesium Research, 21, 92-96.

[187] Nielsen, F.H. and Lukaski, H.C. (2006) Update on the Relationship between Magnesium and Exercise. Magnesium Research, 19, 180-189.

[188] Kass, L.S. and Poeira, F. (2015)The Effect of Acute vs Chronic Magnesium Supplementation on Exercise and Recovery on Resistance Exercise, Blood Pressure and Total Peripheral Resistance on Normotensive Adults. Journal of International Society Sports Nutrition, 12, 1-8. http://dx.doi.org/10.1186/s12970-015-0081-z

[189] Hartzell, H.C. and White, R.E. (1989) Effects of Magnesium on Inactivation of the Voltage-Gated Calcium Current in Cardiac Myocytes. Journal of General Physiology, 94, 745-767. http://dx.doi.org/10.1085/jgp.94.4.745

[190] Restrepo-Angulo, I., De Vizcaya-Ruiz, A. and Camacho, J. (2010) Ion Channels in Toxicology. Journal of Applied Toxicology, 30, 497-512. http://dx.doi.org/10.1002/jat.1556

[191] Kass, G.E., Nicotera, P. and Orrenius, S. (1990) Effects of Xenobiotics on Signal Transduction and Ca ${ }^{2+}$ Mediated $^{2}$ Processes in Mammalian Cells. Princess Takamatsu Symposia, 21, 213-226.

[192] Burgess, J. (2001-2010) Magnesium Absorption and Assimilation. www.afibers.org

[193] Magnesium L-Threonate Reviews, Benefits, Safety and Doses. 2013-2016. www.Nootriment.com 
[194] Martins, I.J. (2016) The Role of Clinical Proteomics, Lipidomics, and Genomics in the Diagnosis of Alzheimer’s Disease. Proteomes, 4, 1-19. http://dx.doi.org/10.3390/proteomes4020014

[195] Leonhard-Marek, S., Gäbel, G. and Martens, H. (1998) Effects of Short Chain Fatty Acids and Carbon Dioxide on Magnesium Transport across Sheep Rumen Epithelium. Experimental Physiology, 83, 155-164. http://dx.doi.org/10.1113/expphysiol.1998.sp004098

[196] Scharrer, E. and Lutz, T. (1990) Effects of Short Chain Fatty Acids and K on Absorption of Mg and Other Cations by the Colon and Caecum. Zeitschrift für Ernährungswissenschaft, 29, 162-168. http://dx.doi.org/10.1007/BF02021554

[197] Wang, Y., Shi, X., Qi, J., Li, X., Uray, K. and Guan, X. (2012) SIRT1 Inhibits the Mouse Intestinal Motility and Epithelial Proliferation. American Journal of Physiology Gastrointestinal Liver Physiology, 302, G207-G217. http://dx.doi.org/10.1152/ajpgi.00302.2011

[198] Golts, N., Snyder, H., Frasier, M., Theisler, C., Choi, P. and Wolozin, B. (2002) Magnesium Inhibits Spontaneous and Iron-Induced Aggregation of Alpha-Synuclein. Journal of Biological Chemistry, 277, 16116-16123. http://dx.doi.org/10.1074/jbc.M107866200

[199] Navarro-Otano, J., Gelpi, E., Mestres, C.A., Quintana, E., Rauek, S., Ribalta, T., et al. (2013) Alpha-Synuclein Aggregates in Epicardial Fat Tissue in Living Subjects without Parkinsonism. Parkinsonism Related Disorders, 19, 27-31. http://dx.doi.org/10.1016/j.parkreldis.2012.07.005 